\title{
Needs Analysis of Synectics Learning Through Developing of Augmented Reality Media for Learning of Narative Story Writing at Institut Pendidikan Indonesia
}

\author{
Deasy Aditya Damayanti ${ }^{1, *}$, Syihabuddin Syihabuddin ${ }^{1}$, Munir Munir $^{2}$, Isah Cahyani $^{1}$ \\ ${ }^{1}$ Indonesian Language Education, ${ }^{2}$ Computer Science \\ Indonesian Education Institute \\ Garut, Indonesia
}

\begin{abstract}
Learning to write narrative stories in the classroom tends to be just an assignment without material reinforcement and feedback. Students do not know where the difficulty is in making narrative stories, so they tend to spend a long time for writing. The problem can be solved by an integrated verbal creativity learning model that can stimulate student ideas to write narrative stories. The research design used was needs assessment research with quantitative approach. The data were collected by questionnaire technique. Data analysis technique used was descriptive statistics with percentage technique. The results showed that the average lecturer's understanding of the concept and position of learning through the development of augmented reality teaching media for learning of narrative story writing was quite understandable and the distribution was evenly distributed. In the needs assessment, there was a tendency that the application of verbal creativity-oriented learning through the development of augmented reality teaching media for learning of narrative story writing was quite necessary and significant. Verbal creativity-oriented learning competencies through the development of augmented reality teaching media for learning of narrative story writing is assumed to be relevant in creative writing courses and motivating in improving the quality and meaningfulness of learning.
\end{abstract}

Keywords—verbal creativity, augmented reality, writing narrative story learning

\section{INTRODUCTION}

According to the theory of active learning which is derived from the philosophy of constructivism education, new ideas are rooted in students' knowledge. Therefore, the best education is based on an analysis of the needs and personal experiences of the students [1]. Students build their own knowledge while they exploring real situations and interacting with other students who may have different perspectives on this situation [2-4]. Many constructivist-based learning models that can be applied in learning the language skills today, one of which is the synectics model. Synectics is a process by using analogies to make something foreign to be familiar. Synectics can be used to help students understand concepts and solve problems. Students are taught how to develop language skills, especially writing by making their own metaphorical connections. According to Gordon, the core of the learning is an analogy that acts as a link between something new and something familiar that allows students to relate facts and experience their experiences with the facts they have just learned.

Regarding the problems in writing narrative story, the researchers got result of observation as follows. It was found that students who almost could not distinguish themes by title, did not know the formal aspects of a narrative story in the form of dialogue, or differentiate a dialogue with narration. When it comes to aspects such as intrinsic elements, they confused for the facts plot, figure, and background story. They were also confused when writing with the first or third point of view. In addition, the use of language style was very inadequate and the themes were developed less relevant to the title. Judging from the integration of elements, the proportions of plots were less balanced, it was less systematic, the dimensions of the characters and the background were less discussed physiologically, psychologically, and sociologically. Judging from the appropriateness of narrative language use, they were too preoccupied with narratives as a result, they ignored The Enhanced Indonesia Spelling System (EYD) and the writing competence. Also, the language variations did not match the dimensions of characters and backgrounds.

The problems can be overcome by providing integrated teaching media on verbal creativity that can help stimulating the students to write ideas, start writing with metaphors, organize the events, help to describe characters and their characteristics, describe the background physiologically, psychologically and sociologically, narrative and coach them for various styles of narrative language styles, The Enhanced Indonesians Spelling System (EYD), and writing competence according to the rules.

Based on the problems above, it is necessary to have a device designed to equip the students a learning media that can support the teaching-learning process becoming more focused and facilitating the understanding of learning materials to achieve the expected competence. The appropriate learning tool to support narrative story writing is augmented reality. 
Augmented Reality is a technology that allows computers to display virtual objects appropriately in a real object directly $[5,6]$. The synectics model will be more meaningful if it is presented in three dimensional form. Regarding this, the media in the form of augmented reality was applied. The use of augmented reality media can concrete something abstract become real and can attract students' interest to learn. Research using this synectics model is still rarely done. Information on the success of this approach is still limited to the results of the study. One of the results of the study using this synectics model shows that the use of synectics model can improve students' learning outcomes.

\section{RESEARCH METHOD}

The research design used was needs assessment research with quantitative approach. The data collection was done by questionnaire technique with structured questionnaire instrument. The data collection was emphasized on the students' perception about: (a) the synectics learning model in narrative story writing, (b) needs, urgency and feasibility of augmented reality media application in narrative story writing, and (c) needs, urgency and augmented reality for learning of narrative story writing.

The data analysis techniques used descriptive statistics, with percentage techniques. To see the tendency of the result of the measurement of variables, the media was used as a comparative norm that was divided into five categories as follows:

TABLE I. TENDENCY CRITERIA

\begin{tabular}{|l|l|}
\hline \multicolumn{1}{|c|}{ Tendency Criteria } & \multicolumn{1}{c|}{ Category } \\
\hline $\mathrm{X} \geq \mathrm{M}+1,5 \mathrm{SD}$ & Very understandable / Very Necessary \\
\hline $\mathrm{M}+0,5 \mathrm{SD} \leq \mathrm{X}<\mathrm{M}+1,5$ & Understandable/ Necessary \\
\hline $\mathrm{M}-0,5 \mathrm{SD} \leq \mathrm{X}<\mathrm{M}+0,5$ & $\begin{array}{l}\text { Sufficiently Understandable/ Sufficiently } \\
\text { Necessary }\end{array}$ \\
\hline $\mathrm{M}-1,5 \mathrm{SD} \leq \mathrm{X}<\mathrm{M}-0,5$ & Less Understandable / Less Necessary \\
\hline $\mathrm{X}<\mathrm{M}-1,5 \mathrm{SD}$ & Ununderstandable/ Unnecessary \\
\hline
\end{tabular}

The distance determination of 1.5 SD for this category is based on the normal distribution curve which is theoretically within 6 standard deviations (6SD) [7]. To calculate the median (M) and standard deviation (SD), formula used are as follows:

$$
\begin{aligned}
& M=1 / 2(\text { highest ideal value }+ \text { lowest ideal value) } \\
& M=1 / 2(5+1) \\
& S D=1 / 6 \text { (highest ideal value }- \text { lowest ideal value) } \\
& S D=1 / 6(5-1)
\end{aligned}
$$

\section{RESULTS}

The findings of the research in the needs assessment were used as the basis for the design of the planning, implementation and evaluation of the synectics learning model through the development of augmented reality media for learning of narrative story writing at INSTITUT PENDIDIKAN INDONESIA as a form of support to improve the learning quality and the students' quality.

Comprehensively, this research is part of a strategic step in achieving the quality and quality of education by optimizing the utilization of augmented reality in the context of learning of narrative story writing inside campus or outside campus area. Questionnaires distributed in this study in accordance with the data obtained as much as 53 respondents from the sample of students in Institute Pendidikan Indonesia. The following is presented research data relating to understanding the concept and position of synoptic learning through the development of augmented reality media for learning to write narrative stories at Institute Pendidikan Indonesia.

\section{A. Understanding the Concept and Position of Synectic}

Learning through Development of Augmented Reality Media in Writing Narrative Story in Institut Pendidikan Indonesia

Based on the data collected, the data about the understanding of the concept and the position of synectics learning through the development of augmented reality media in writing narrative stories as follows. The lowest score is 52 and the highest 78 with the mean of 64,51 and the standard deviation of 5,13. To find out the tendency, the calculation of percentage of tendency and comparative criterion by using ideal mean score and ideal standard deviation was used. The result of the calculation shows that the respondent's understanding about the concept and the position of synectics learning through the development of augmented reality media in writing narrative story at Institute Pendidikan Indonesia, are in very understandable category $26,4 \%$, understandable category $69,8 \%$, and sufficiently understandable category $3,8 \%$. From the mean or average scores, the understanding of the concept and the position of synectics learning through the development of augmented reality media in writing narrative story is in the category of understandable category. More details perception percentage of understanding can be seen in the following table 2 and 3 .

$$
\begin{aligned}
& \text { Highest ideal value }=5 \times 17=85 \\
& \text { Lowest ideal value }=1 \times 17=17 \\
& M=1 / 2(\text { highest ideal value }+ \text { lowest ideal value) } \\
& \quad=1 / 2(85+17)=1 / 2(102)=51
\end{aligned}
$$

$\mathrm{SD}=1 / 6$ (highest ideal value - lowest ideal value) $\mathrm{SD}$

$$
=1 / 6(85-17)=1 / 6(68)=11,3
$$


TABLE II. VARIABLE TENDENCY OF UNDERSTANDING OF CONCEPT AND POSITION OF SYNECTICS LEARNING THROUGH THE DEVELOPMENT OF AUGMENTED REALITY MEDIA IN WritING NARRATIVE STORY IN INSTITUT PENDIDIKAN INDONESIA

\begin{tabular}{|l|l|}
\hline \multicolumn{1}{|c|}{ Tendency Criteria } & \multicolumn{1}{c|}{ Category } \\
\hline $\mathrm{X} \geq \mathrm{M}+1,5 \mathrm{SD}$ & Very understandable / \\
$\mathrm{X} \geq 51+1,5(11,3)$ & Very Necessary \\
$\mathrm{X} \geq 51+16,95$ & \\
$\mathrm{X} \geq 67,95$ & \\
\hline $\mathrm{M}+0,5 \mathrm{SD} \leq \mathrm{X}<\mathrm{M}+1,5 \mathrm{SD}$ & \\
$51+0,5(11,3) \leq \mathrm{X}<51+1,5(11,3)$ & \\
$51+5,65 \leq \mathrm{X}<67,95$ & \\
$56,65 \leq \mathrm{X}<67,95$ & \\
\hline $\mathrm{M}-0,5 \mathrm{SD} \leq \mathrm{X}<\mathrm{M}+0,5 \mathrm{SD}$ & Sufficiently \\
$51-5,65 \leq \mathrm{X}<51+5,65$ & Understandable/ \\
$45,35 \leq \mathrm{X}<56,65$ & Sufficiently Necessary \\
\hline $\mathrm{M}-1,5 \mathrm{SD} \leq \mathrm{X}<\mathrm{M}-0,5 \mathrm{SD}$ & Less Understandable / Less \\
$51-16,95 \leq \mathrm{X}<45,35$ & Necessary \\
$34,5 \leq \mathrm{X}<45,35$ & \\
\hline $\mathrm{X}<\mathrm{M}-1,5 \mathrm{SD}$ & Ununderstandable/ \\
$\mathrm{X}<34,5$ & Unnecessary \\
\hline
\end{tabular}

TABLE III. RESULTS TENDENCY OF UNDERSTANDING OF CONCEPT AND POSITION OF SYNECTICS LEARNING THROUGH THE DEVELOPMENT OF AUGMENTED REALITY MEDIA IN WRITING NARRATIVE STORY IN INSTITUT PENDIDIKAN INDONESIA

\begin{tabular}{|l|l|l|l|}
\hline \multicolumn{1}{|c|}{ Score } & \multicolumn{1}{c|}{ Category } & Frequency & Percentage \\
\hline 67,95 and above & Very understandable & 14 & $26,64 \%$ \\
\hline $56,65-67,94$ & Understandable & 37 & $69,8 \%$ \\
\hline $45,35-56,64$ & $\begin{array}{l}\text { Sufficiently } \\
\text { Understandable }\end{array}$ & 2 & $3,8 \%$ \\
\hline $34,5-45,34$ & Less Understandable & 0 & $0,0 \%$ \\
\hline 34,4 and below & Ununderstandable & 0 & $0,0 \%$ \\
\hline Total & & 53 & 100 \\
\hline
\end{tabular}

\section{B. The Need of Application of Synectics Learning through the} Development of Augmented Reality Media in Writing Narrative Story at Institut Pendidikan Indonesia

Based on data collected, it is found that the need of application of Synectics Learning through the Development of Augmented Reality Media in Writing Narrative Story at Institute Pendidikan Indonesia as follows. The lowest score is 47 and the highest is 82 with the average of 65,13 and the standard deviation of 6,22 . To find out the tendency, the calculation of the percentage of tendencies and comparative criteria as described previously with using the ideal average score and ideal standard deviation was used. The calculation results show that the need of application of Synectics Learning through the Development of Augmented Reality Media in Writing Narrative Story in Institute Pendidikan Indonesia are classified as very necessary category $24,64 \%$, necessary category $67.9 \%$, and sufficiently necessary category $5,7 \%$. From mean or the average scores, the requirement of Application of Synectics Learning through the Development of Media Augmented Reality in Writing Narrative Story at Institute Pendidikan Indonesia from respondents is quite necessary. More details of this percentage of the trend can be seen in the following table 4 and 5.

$$
\text { Highest ideal value }=5 \times 17=85
$$$$
\text { Lowest ideal value }=1 \times 17=17
$$

$M=1 / 2$ (highest ideal value + lowest ideal value)

$$
=1 / 2(85+17)=1 / 2(102)=51
$$

$\mathrm{SD}=1 / 6$ (highest ideal value - lowest ideal value) $\mathrm{SD}$

$$
=1 / 6(85-17)=1 / 6(68)=11,3
$$

TABLE IV TENDENCY OF APPLICATION OF SYNECTICS LEARNING THROUGH THE DEVELOPMENT OF AUGMENTED REALITY MEDIA IN WRITING NARRATIVE STORY AT INSTITUT PENDIDIKAN INDONESIA VARIABLE

\begin{tabular}{|l|l|}
\hline \multicolumn{1}{|c|}{ Tendency Criteria } & \multicolumn{1}{|c|}{ Category } \\
\hline $\mathrm{X} \geq \mathrm{M}+1,5 \mathrm{SD}$ & Very understandable / Very \\
$\mathrm{X} \geq 51+1,5(11,3)$ & \\
$\mathrm{X} \geq 51+16,95$ & \\
$\mathrm{X} \geq 67,95$ & Understandable/ Necessary \\
$\mathrm{M}+0,5 \mathrm{SD} \leq \mathrm{X}<\mathrm{M}+1,5 \mathrm{SD}$ & \\
$51+0,5(11,3) \leq \mathrm{X}<51+1,5$ & \\
$(11,3)$ & \\
$51+5,65 \leq \mathrm{X}<67,95$ & \\
$56,65 \leq \mathrm{X}<67,95$ & Sufficiently Understandable/ \\
$\mathrm{M}-0,5 \mathrm{SD} \leq \mathrm{X}<\mathrm{M}+0,5 \mathrm{SD}$ & Sufficiently Necessary \\
$51-5,65 \leq \mathrm{X}<51+5,65$ & \\
$45,35 \leq \mathrm{X}<56,65$ & Less Understandable / Less \\
\hline $\mathrm{M}-1,5 \mathrm{SD} \leq \mathrm{X}<\mathrm{M}-0,5 \mathrm{SD}$ & Necessary \\
$51-16,95 \leq \mathrm{X}<45,35$ & \\
$34,5 \leq \mathrm{X}<45,35$ & Ununderstandable/ \\
\hline $\mathrm{X}<\mathrm{M}-1,5 \mathrm{SD}$ & Unnecessary \\
$\mathrm{X}<34,5$ &
\end{tabular}

TABLE V. RESUlts TENDENCY OF APPLICATION OF SYNECTICS LEARNING THROUGH THE DEVELOPMENT OF AUGMENTED REALITY MEDIA IN WRITING NARRATIVE STORY AT INSTITUT PENDIDIKAN INDONESIA VARIABLE

\begin{tabular}{|l|l|l|l|}
\hline \multicolumn{1}{|c|}{ Score } & \multicolumn{1}{|c|}{ Category } & Frequency & Percentage \\
\hline 67,95 and above & $\begin{array}{l}\text { Very } \\
\text { Understandable }\end{array}$ & 14 & $26,64 \%$ \\
\hline $56,65-67,94$ & Understandable & 36 & $69,8 \%$ \\
\hline $45,35-56,64$ & $\begin{array}{l}\text { Sufficiently } \\
\text { Understandable }\end{array}$ & 3 & $3,8 \%$ \\
\hline $34,5-45,34$ & Less Understandable & 0 & $0,0 \%$ \\
\hline 34,4 and below & Ununderstandable & 0 & $0,0 \%$ \\
\hline Total & & 53 & 100 \\
\hline
\end{tabular}

C. The Need, Urgency, and Application of Augmented Reality Media in Learning to Write Narrative Stories at Institut Pendidikan Indonesia

Based on data collected, it is found that the needs of application of media application Augmented Reality in Writing Narrative Story in Institute Pendidikan Indonesia is as follows. The lowest score is 56 and the highest is 94 with the average of 74,98 and the standard deviation of 8,26 To find out the tendency, the calculation of the percentage of tendencies and comparative criteria as described previously with using the ideal average score and ideal standard deviation was used. The calculation results show that the needs of Application of Media Augmented Reality Approach in Learning of Narrative Story Writing at Institute Pendidikan Indonesia is classified into very necessary category $28,3 \%$, necessary category $54,7 \%$, and sufficiently necessary category $17,0 \%$. From mean or the average score, the need of Application of Augmented Reality Media in Learning of Narrative Story Writing at Institute Pendidikan Indonesia from respondents belongs to category of 
sufficiently necessary. More details of this percentage of the trend can be seen in the following Table 6 and 7.

Highest ideal value + lowest ideal value

Highest ideal value $=5 \times 20=100$

Lowest ideal value $=1 \times 20=20$

$M=1 / 2$ (highest ideal value + lowest ideal value)

$=1 / 2(100+20)=1 / 2(120)=60$

$\mathrm{SD}=1 / 6$ (highest ideal value - lowest ideal value) $\mathrm{SD}$

$$
=1 / 6(100-20)=1 / 6(80)=13,3
$$

TABLE VI. VARIABLE TENDENCY OF APPlCATION OF AUGMENTED REALITY MEDIA IN WRITING NARRATIVE STORY AT INSTITUT PENDIDIKAN INDONESIA

\begin{tabular}{|l|l|}
\hline \multicolumn{1}{|c|}{ Tendency Criteria } & \multicolumn{1}{c|}{ Category } \\
\hline $\mathrm{X} \geq \mathrm{M}+1,5 \mathrm{SD}$ & Very understandable / Very \\
$\mathrm{X} \geq 60+1,5(13,3)$ & \\
$\mathrm{X} \geq 60+19,95$ & \\
$\mathrm{X} \geq 79,95$ & Understandable/ Necessary \\
\hline $\mathrm{M}+0,5 \mathrm{SD} \leq \mathrm{X}<\mathrm{M}+1,5 \mathrm{SD}$ & \\
$60+0,5(13,3) \leq \mathrm{X}<60+1,5$ & \\
$(13,3)$ & \\
$60+6,65 \leq \mathrm{X}<79,95$ & Sufficiently Understandable/ \\
$66,65 \leq \mathrm{X}<79,95$ & Sufficiently Necessary \\
\hline $\mathrm{M}-0,5 \mathrm{SD} \leq \mathrm{X}<\mathrm{M}+0,5 \mathrm{SD}$ & \\
$60-6,65 \leq \mathrm{X}<60+6,65$ & Less Understandable / Less \\
$53,35 \leq \mathrm{X}<66,65$ & Necessary \\
\hline $\mathrm{M}-1,5 \mathrm{SD} \leq \mathrm{X}<\mathrm{M}-0,5 \mathrm{SD}$ & \\
$60-19,95 \leq \mathrm{X}<53,35$ & Understandable/ Unnecessary \\
$40,05 \leq \mathrm{X}<53,35$ & \\
\hline $\mathrm{X}<\mathrm{M}-1,5 \mathrm{SD}$ & \\
$\mathrm{X}<40,05$ & \\
\hline
\end{tabular}

TABLE VII. RESULTS TENDENCY OF APPLICATION OF AUGMENTED REALITY MEDIA IN WRITING NARRATIVE STORY AT INSTITUT PENDIDIKAN INDONESIA

\begin{tabular}{|l|l|c|c|}
\hline \multicolumn{1}{|c|}{ Score } & \multicolumn{1}{|c|}{ Category } & Frequency & Percentage \\
\hline 79,95 and above & $\begin{array}{l}\text { Very } \\
\text { Understandable }\end{array}$ & 15 & 28,3 \\
\hline $66,65-79,94$ & Understandable & 29 & 54,7 \\
\hline $53,35-66,64$ & $\begin{array}{l}\text { Sufficiently } \\
\text { Understandable }\end{array}$ & 9 & 17,0 \\
\hline $40,05-53,34$ & Less Understandable & 0 & 0,0 \\
\hline $\begin{array}{l}40,04 \\
\text { below and }\end{array}$ & Understandable & 0 & 0,0 \\
\hline Total & & 53 & 100,0 \\
\hline
\end{tabular}

\section{CONCLUSION}

In the needs assessment, there was a tendency that the application of verbal creativity-oriented learning through the development of augmented reality teaching media for learning of narrative story writing was quite necessary and significant. Verbal creativity-oriented learning competencies through the development of augmented reality teaching media for learning of narrative story writing is assumed to be relevant in creative writing courses and motivating in improving the quality and meaningfulness of learning.

\section{ACKNOWLEDGMENT}

Students thanks to Allah Swt, Prof. Dr. Syihabuddin, Prof. Munir, M.IT, Dr. Hj. Isah Cahyani, Dr. H. Andoyo Sastromiharjo, Dr. Vismaia S. Damaianti, Dr. Yeti Mulyati, Dr. Sumiyadi, Dr. Hj. Lina Siti Nurwahidah, Tina Sri Sumartini, M. Pd, Ramdanul Barkah, S.Pd., and Irena Puji Luritawaty, M. Pd.

\section{REFERENCES}

[1] R.S. Prawat and R.E. Floden, "Philosophical perspectives on constructivist views of learning," Educational psychologist, vol. 29, no. 1, pp. 37-48, 1994.

[2] B. Jaworsk, Investigating Mathematics Teaching: A Constructivist Enquiry, Bristol, P. Falmer Print, 1994.

[3] C.T. Fosnot, Constructivism: Theory, Perspectives, and Practice, College Teachers Prints, 1996, p. 234-278.

[4] L. Steff and J. Gale, Constructivism in education.Hillsdale, NJ: Erlbaum, 1995, p. 459-486.

[5] P. Milgram and F. Kishino, "A Taxonomy of Mixed Reality Visual Displays," IEICE Transactions on Information Systems E77-D12, pp. 1321-1329, 1994

[6] P. Milgram, H. Takemura, A. Utsumi and F. Kishino, "Augmented reality: A class of displays on the reality-virtuality continuum," In Telemanipulator and telepresence technologies, vol. 2351, pp. 282-292, 1995.

[7] S. Hadi, Metodology Research 3, 1986. 